\title{
EFFECT OF DIFFERENT PACKAGING SYSTEMS AND REFRIGERATED CONDITION ON COCONUT APPLE QUALITY
}

\author{
B. KARTHIKEYAN ${ }^{1}$, E. ELAKKIYA ${ }^{2}$, C. ASHOKKUMAR ${ }^{3} \&$ D. BASKARAN $^{4}$ \\ ${ }^{I}$ Assistant Professor, College of Food and Dairy Technology, TANUVAS, Chennai, Tamil Nadu, India \\ ${ }^{2}$ College of Food and Dairy Technology, TANUVAS, Chennai, Tamil Nadu, India \\ ${ }^{3}$ Research Scholar, College of Food and Dairy Technology, TANUVAS, Chennai, Tamil Nadu, India \\ ${ }^{4}$ Dean, College of Food and Dairy Technology, TANUVAS, Chennai, Tamil Nadu, India
}

\begin{abstract}
The shelf life study of coconut apple, was done by different packaging systems. The effect of vacuum packing and aerobic packing, on the shelf-life of coconut apple was investigated, during storage periods. The microbial, chemical and sensory changes were analyzed, throughout the storage time. After packing, samples were immediately stored at $4 \pm 1^{\circ} \mathrm{C}$, samples of air and vacuum packaging were drawn on the $0,3,6$, and $9^{\text {th }}$ day of storage evaluated. The proximate values (crude protein, crude fiber, fat, carbohydrate, moisture, ash, etc.) and microbial quality (SPC, Psychrophillic and Yeast \& mould) also evaluated. The results showed that, the vacuum packaging system extended the shelf life, two fold than the aerobic packaging system under refrigeration.

KEYWORDS: Coconut Apple, Normal Seal, Vacuum Seal \& Shelf Life
\end{abstract}

Received: Aug 17, 2017; Accepted: Sep 04, 2017; Published: Sep 11, 2017; Paper Id.: IJASROCT201720

\section{INTRODUCTION}

The coconut (Cocos nucifera L.) is an important fruit tree in the tropical regions. India is the world's third largest producer of coconuts, producing 22,167.45 million nuts, per annum. The coconuts are referred to as "nuts of India" and has been designated several other names. The fruit can be made into a variety of foods and beverages. More than $50 \%$ of nuts are consumed raw in the household sector and some in the form of ready to eat sweet meats, using sugar and jiggery (Satyanarayana Rao et al., 1990). Coconuts are eaten at different stages and in many different ways. The white nut-meat can be eaten raw or shredded and dried, and used in most cooking recipes. More than 100 products made directly or indirectly from the coconuts, seven are of vital importance to world trade - whole coconut, copra, coconut oil cake, coir, desiccated shredded coconut, coconut skin milk and protein. One of the primary natural products, produced from the dry fruit (copra) of coconut is coconut oil, which has been used from time immemorial as food, food ingredient and functional foods, besides used in pharmaceuticals, Nutraceuticals, cosmetics and industrial uses, including bio fuel. In India, coconut economy depends mainly on coconut oil.

Apart from these primary products, many delicacies can be made from coconut. When a coconut begins to germinate, small, firm, white flesh can be found in the north (often called germinating coconut or endosperm). This can be eaten raw in salads or as a snack. The coconut endosperm is a rich medium for the growth of many spoilage microorganisms. In addition, it is highly susceptible to chemical deterioration, by lipid auto oxidation and lipolysis. 
Despite the fact that, coconut has been processed into many food products some of which like coconut milk, coconut grate are indispensable ingredient, in many of the traditional cuisine of south Asian countries, information on the spoilage pattern of coconut, organisms that cause spoilage and more importantly, the effect of spoilage on the nutritional content of this produce is very sparse.

Vacuum packing has become popular as a protection technique during refrigeration. Shelf life quality of perishable food products can be improved by vacuum packing technique. Moreover, the microbial ecology of food basically, depends on the environment, used equipment, food type, handling practices, processing, packaging and storage temperature (Parry, 1993; Krizek et al., 2004; Ozogul et al., 2004; Sachindra et al., 2005).

The present investigation was aimed to extend the shelf life of coconut apple, by different packaging systems and hence, it could be stored at ambient as well as at refrigerated temperature.

\section{MATERIALS AND METHODS}

\section{Determination of $\mathrm{pH}$ and Acidity}

The $\mathrm{pH}$ and acidity of coconut apple samples were measured, as per the method outlined by (AOAC, 2005). The $\mathrm{pH}$ meter was standardized with a standard buffer solution of $\mathrm{pH} 4$ and 7.

\section{Determination of Peroxide Value}

The Peroxide value (PV) of extracting coconut apple was determined, according to AOCS method (AOCS, 1992).

\section{Determination of Free Fatty Acids}

The Free Fatty Acid present in the samples was estimated, by extracting it with alcoholic ether (neutralized) and titrating with $0.1 \mathrm{~N}$ sodium hydroxide as per AOAC. (1990).

\section{Determination of Proximate Composition}

The methods of the Association of Official Analytical chemist (AOAC, 1990) were used, for determination of moisture, crude protein, crude fiber, fat, total ash, and Nitrogen free extract of the RTE snack. All the determinations were done in triplicates.

\section{Microbiological Quality}

Total plate count, Psychrophilic count and Yeast \& mould counts were determined, by following the method of APHA (1992). Ten $\mathrm{g}$ of aseptically packed coconut apple sample and $90 \mathrm{ml}$ of $0.1 \%$ sterile peptone water, was triturated in a sterile in a sterile mortor, for uniform dispersion to get $10^{-1}$ dilution. Further, serial tenfold dilution was made in presterilized tubes, containing $9 \mathrm{ml}$ of $0.1 \%$ peptone water. All the dilutions were made by observing all possible aseptic precautions.

\section{Total Plate Count}

About $23.5 \mathrm{~g}$ of plate count agar (Hi-media Pvt. Ltd.), was suspended in one litre of distilled water. It was boiled to dissolve completely, and sterilized by autoclaving at $15 \mathrm{lbs}$ pressure for $15 \mathrm{~min}$. The pour plate technique was followed for plating, using $1 \mathrm{ml}$ of inoculums in duplicate from appropriate dilutions. The plates were incubated at $37 \pm 1^{\circ} \mathrm{C}$, for 48 hrs. Following incubation, plates showing 30 to 300 colonies were selected for counting. The number of colonies counted were multiplied by the reciprocal of respective dilutions, and expressed as $\log _{10} \mathrm{cfu} / \mathrm{g}$. 


\section{Psychrophilic Count}

The procedure outlined for total plate count, was followed for psychrophilic count except incubation, where the plated were incubated at $4 \pm 1^{\circ} \mathrm{C}$ for 7 days. Colonies were counted and the results were expressed in a similar way.

\section{Yeast \& Mould Count}

Sabourd and Dextrose agar (65.0 g) was suspended in one litre of distilled water, and sterilized by autoclaving at $15 \mathrm{lbs}$ pressure for $15 \mathrm{~min}$. After cooling to $45^{\circ} \mathrm{C}$, the medium was poured over the plates in duplicate, containing $1 \mathrm{ml}$ of inoculums, of suitable dilution. The petri plates were incubated at $25 \pm 1^{\circ} \mathrm{C}$, for 5 days. Black, White, red or greenish black coloured colonies appeared in the plates, were counted and expressed as $\log _{10} \mathrm{cfu} / \mathrm{g}$.

\section{Storage Study}

The coconut apple packed in aerobic and vacuum packages, then the materials stored under refrigerated condition, the temperature maintained at below $5^{\circ} \mathrm{C}$ and the samples subjected to storage study, for the period of 15 days. The physico-chemical and microbiological parameters for the product were analyzed, as per standard methods. Shelf life studies were conducted at specific intervals, and the corresponding changes in microbiological, physicochemical, proximate and sensory characteristics were observed.

\section{Sensory Evaluation}

The sensory panellists (20 semi trained), were academic staff and students of the college of food and dairy Technology, koduvalli. The panelist was instructed to assess the quality of coconut apple, on the basis of sensory attributes such as appearance, flavor, texture and overall acceptability, using 8 point descriptive scale, where $8=$ like extremely, $7=$ like very much, $6=$ like moderately, $5=$ like slightly, $4=$ dislike slightly, $3=$ dislike moderately, $2=$ dislike very much and $1=$ dislike extremely. The analysis of two different treatments in six replications was done, and the results were reported as the average.

\section{RESULTS AND DISCUSSIONS}

\section{Physicochemical Analysis of Coconut Apple Packed Under Vacuum Packaging System on Refrigeration Storage}

The observations with regard to physicochemical analysis of coconut, apple, packed under vacuum packaging system on refrigeration storage are shown in the Table 1 . The $\mathrm{pH}$, titratable acidity, peroxide value, free fatty acids and moisture, followed the increasing trend till the end of storage period. The remaining parameters viz crude protein, crude fibre, ether extract, total ash showed decreasing trend. The findings of the present study are in accordance with Viduranga et al., 2007, who also observed the FFA contents and peroxide values increased steadily, with the increase in storage time in his experiment, where the pre-treatments is suppressing the chemical and enzymatic deterioration of coconut kernels. The value for which, the PV indicates the onset of rancidity is $35.5 \mathrm{meq}$, of peroxide $\mathrm{O}_{2}$ per $\mathrm{kg}$ of oil (Anon, 1985). The gradual increment in free fatty acids may be, due to the microbial lipase that may have been produced due to growth of microorganisms during storage. In this study, the peroxide value is below the rancid limit, that is 33.5 meq of peroxide $\mathrm{O} 2$ per $\mathrm{kg}$ of oil. It is concluded that, a vacuum packaging system with refrigeration can maintain the shelf life up to 9 days, without affecting sensory parameters. 
Table 1: Physicochemical Analysis of Coconut Apple Packed Under Vacuum Packaging System for Refrigeration Storage

\begin{tabular}{|c|l|c|c|c|c|}
\hline \multirow{2}{*}{ S. No Parameters } & \multicolumn{4}{|c|}{ Storage Period (Days) } \\
\cline { 3 - 6 } & & 0 & 3rd & 6th & 9th \\
\hline 1. & pH & 5.9 & 6.2 & 6.5 & 7.2 \\
\hline 2. & Titratable acidity (\%) & 0.15 & 0.15 & 0.18 & 0.25 \\
\hline 3. & Peroxide value (meq of peroxide O2 per kg of oil) & 22.5 & 26.7 & 25.5 & 33.5 \\
\hline 4. & Free fatty acids & 0.55 & 0.58 & 0.60 & 0.65 \\
\hline 5. & Moisture (\%) & 79.92 & 82.50 & 83.96 & 85.35 \\
\hline 6. & Crude protein (\%) & 9.08 & 8.80 & 8.48 & 7.80 \\
\hline 7. & Crude fibre (\%) & 5.82 & 5.61 & 5.55 & 5.50 \\
\hline 8. & Ether extract (\%) & 11.76 & 9.30 & 7.51 & 7.42 \\
\hline 9. & Total ash (\%) & 10.55 & 8.56 & 8.52 & 8.45 \\
\hline 10. & Nitrogen Free Extract (NFE) & 67.64 & 65.52 & 65.09 & 64.25 \\
\hline
\end{tabular}

Physicochemical Analysis of Coconut Apple Packed under Aerobic Packaging System on Refrigeration Storage

The observations with regard to physicochemical analysis of coconut, apple, packed under the aerobic packaging system in refrigerated storage were given in Table 2. The $\mathrm{pH}$, titratable acidity, peroxide value, free fatty acids and moisture, followed the increasing trend to the end of storage period. The remaining parameters viz crude protein, crude fibre, ether extract, total ash showed decreasing trend. The free fatty acids and peroxide values exceeded the maximum limit and it indicated the signs of microbial and enzymatic rancidity, resulted in unacceptable quality. Hence, it could be concluded that, the coconut apple stored under the aerobic system with refrigerant, could maintain the product without affecting the sensory attributes, upto 3 days of storage period.

Table 2: Physicochemical Analysis of Coconut Apple Packed Under Aerobic Packaging System for Refrigeration Storage

\begin{tabular}{|c|l|c|c|c|c|}
\hline \multirow{2}{*}{ S. No } & \multirow{2}{*}{ Parameters } & \multicolumn{3}{|c|}{ Storage Period (Days) } \\
\cline { 3 - 6 } & & $\mathbf{0}$ & $\mathbf{3}^{\text {rd }}$ & $\mathbf{6}^{\text {th }}$ & $\mathbf{9}^{\text {th }}$ \\
\hline 1. & $\mathrm{pH}$ & 5.8 & 6.7 & 7.5 & 8.8 \\
\hline 2. & Titratable acidity (\%) & 0.14 & 0.17 & 0.30 & 0.35 \\
\hline 3. & Peroxide value (meq of peroxide O2 per kg of oil) & 22.12 & 24.50 & 34.5 & 37.40 \\
\hline 4. & Free fatty acids & 0.53 & 0.65 & 0.75 & 0.86 \\
\hline 5. & Moisture (\%) & 80.24 & 83.00 & 83.25 & 84.24 \\
\hline 6. & Crude protein (\%) & 9.25 & 8.50 & 7.25 & 7.02 \\
\hline 7. & Crude fibre (\%) & 5.72 & 5.52 & 5.44 & 5.35 \\
\hline 8. & Ether extract (\%) & 11.35 & 7.55 & 6.03 & 5.08 \\
\hline 9. & Total ash (\%) & 10.60 & 8.62 & 7.90 & 7.45 \\
\hline 10. & Nitrogen Free Extract (NFE) & 67.45 & 65.25 & 64.25 & 62.34 \\
\hline
\end{tabular}

Microbiological Study of Coconut Apple Packed under Vacuum Packaging System on Refrigeration Storage

The observations with regard to microbiological study of coconut apple, packed under vacuum packaging system on refrigeration storage are shown in figure 1. The standard plate count, Psychrophillic count, yeast and mould count of coconut apple, were observed to be increased with the progress of storage. Kumar and Sharma (2003), reported increases in plate count in low fat ground pork patties during storage of 21 days. The findings of the present study were in accordance with Kalaikannan et al., (2007) who also reported marked, but a linear increase in microbial counts of chicken patties, incorporated with the whole egg liquid. However, all the counts were within permissible limits. Hence, it is concluded that, a vacuum packaging system with refrigeration could maintain the coconut apple, upto $9^{\text {th }}$ day without affecting sensory qualities. 




Figure 1: Microbiological Study of Coconut Apple Packed under Vacuum Packaging System on Refrigeration Storage

\section{Microbiological Study of Coconut Apple Packed under Aerobic Packaging System on Refrigeration Storage}

The observations with regard to microbiological study of coconut apple, packed under the aerobic packaging system in refrigerated storage are shown in Figure 2. The standard plate count, Psychrophillic count, yeast and mould count of coconut apple, were observed to be increased with the progress of storage at very faster rate, than vacuum packed. Raut (2007), also reported significant increase in total plate count, as well as yeast and mould count in soya extended chicken patties, during refrigerated storage. The increased number of colonies indicated that, the samples were heavily spoiled on $6^{\text {th }}$ and $9^{\text {th }}$ days of refrigeration storage.

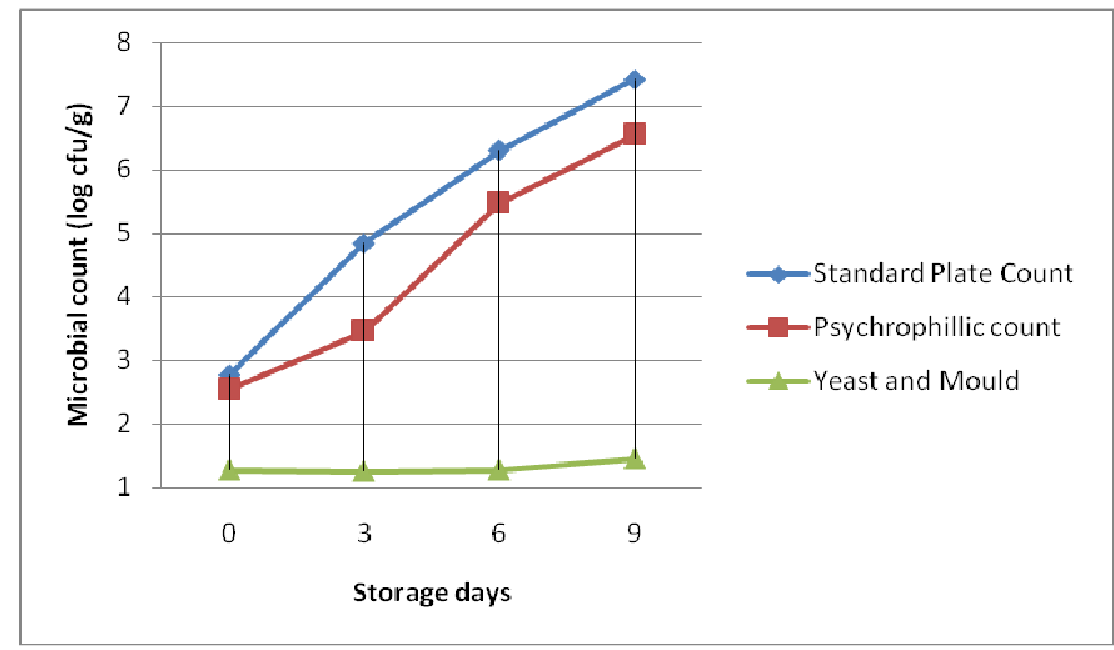

Figure 2: Microbiological Study of Coconut Apple Packed under Aerobic Packaging System on Refrigeration Storage

\section{Sensory Evaluation of Coconut Apple Packed under Vacuum Packaging System on Refrigeration Storage}

The observations with regard to Sensory evaluation of coconut, apple packed under vacuum packaging system, on refrigeration storage are shown in Figure 3 . The average scores of appearance were $7.16,7.05,6.73,5.82$ to $0,3^{\text {rd }}, 6^{\text {th }}, 9^{\text {th }}$ days, respectively. The average scores of flavor were $7.12,7.01,6.83,5.54$ to $0,3^{\text {rd }}, 6^{\text {th }}, 9^{\text {th }}$ days, respectively. The average 
scores of texture were $7.20,7.13,6.96,5.77$ to $0,3^{\text {rd }}, 6^{\text {th }}, 9^{\text {th }}$ days, respectively. The average scores of overall acceptability were $7.28,7.22,6.67,5.74$ to $0,3^{\text {rd }}, 6^{\text {th }}, 9^{\text {th }}$ days, respectively.

It is seen that, the average scores of all sensory attributes decreased with the progress of storage period. Due to slight rancid odour observed, the scores reached fair to slightly palatable at $9^{\text {th }}$ day, but still it can be consumed.

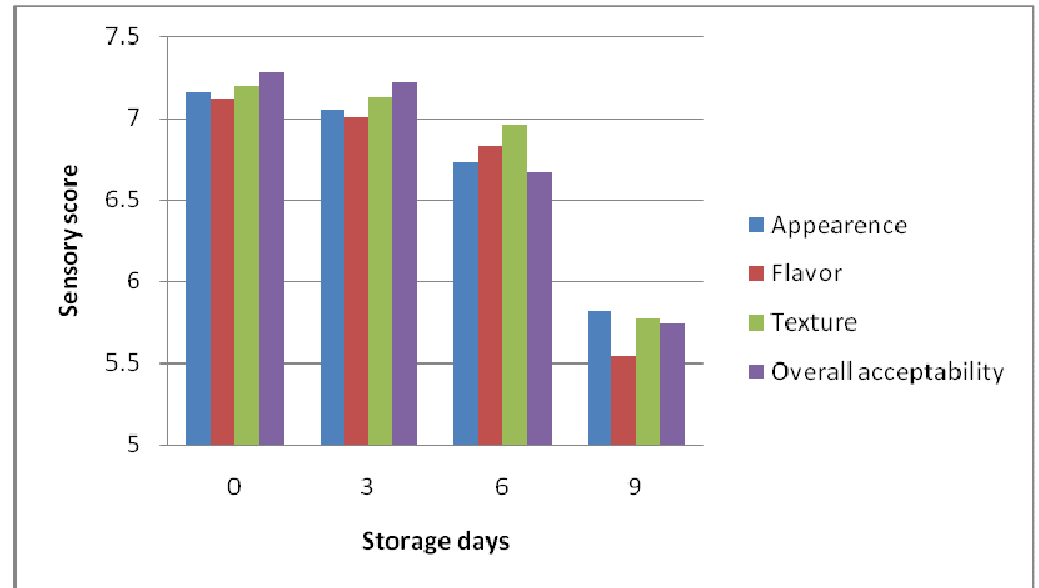

Figure 3: Sensory Evaluation of Coconut Apple Packed under Vacuum Packaging System on Refrigeration Storage

\section{Sensory Evaluation of Coconut Apple Packed under Aerobic Packaging System on Refrigeration Storage}

The observations, with regard to Sensory evaluation of coconut apple, packed under the aerobic packaging system in refrigerated storage are shown in figure 4 . The average scores of appearance were $7.24,6.76,4.42,4.14$ to $0,3^{\text {rd }}, 6^{\text {th }}, 9^{\text {th }}$ days, respectively. The average scores of flavor were $7.15,6.56,4.46,4.23$ to $0,3^{\text {rd }}, 6^{\text {th }}, 9^{\text {th }}$ days, respectively. The average scores of texture were $7.23,6.62,4.40,4.31$ to $0,3^{\text {rd }}, 6^{\text {th }}, 9^{\text {th }}$ days, respectively. The average scores of overall acceptability were $7.21,6.67,4.45,4.23$ to $0,3^{\text {rd }}, 6^{\text {th }}, 9^{\text {th }}$ days, respectively.

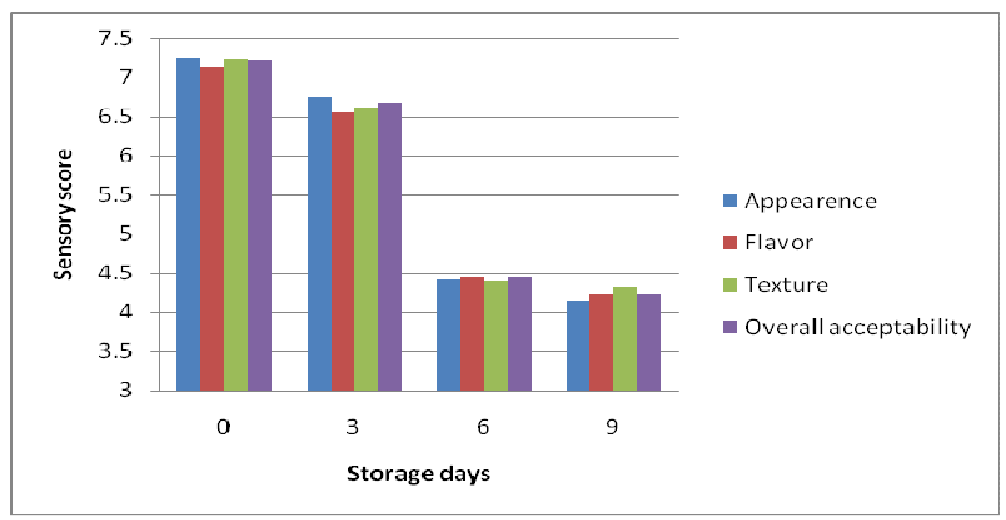

Figure 4: Sensory Evaluation of Coconut Apple Packed under Aerobic Packaging System on Refrigeration Storage

It is seen that, the average scores of all sensory attributes decreased with the progress of storage period. On day of the 6th the average scores, for sensory attributes reached slightly poor to slightly unpalatable, so it is concluded that, in the aerobic packaging system the coconut apple may be consumed upto $3^{\text {rd }}$ day. 


\section{CONCLUSIONS}

The aerobic packaging system extended the shelf life of coconut, apple, upto 3 days under refrigeration. The vacuum packaging system extended the shelf life of coconut, apple upto 9 days, under refrigeration. It is expected that, the vacuum package system may extend the shelf life to minimum of 20 - 30 days, but the samples become rancid after the 10th day. The use of opaque packaging material and pre treatment, with natural or chemical preservatives may extend the shelf life further.

\section{REFERENCES}

1. Adkins, S.W., M. Foale and Y.M.S. Samosir. (2005). Coconut revival-new possibilities for the 'tree of life'. Proceedings of the International Coconut Forum held in Cairns, 22-24.

2. Anitha Madhusoodhanan Chikku and Thankappan Rajamohan. (2012). Dietary coconut sprout beneficially modulates cardiac damage induced by isoproterenol in rats, J. Pharmacol 7: 258-265.

3. AOAC (1995). Official Methods of Analysis, 16th Edn. Association of Official Analytical Chemists, Washington, D.C.

4. AOAC. (1990). Official methods of analysis, Association of Official analytical chemists, Washington, D.C., U.S.A. 15 ${ }^{\text {th }}$ edition, $807-928$

5. APHA (1992). Compendium of methods for the microbilological examination of foods. Speck, M. L. (Ed.) American Public Health Association.

6. Campbell-Falck D. Thomas T. Falck TM. Tutuo N. Clem K, The intravenous use of coconut water. American Journal of Emergency Medicine, 2000, 18 (1): 108-111.

7. Consignado, T. O., Tabora Jr., P. C., \& Creencia, R. P. (1976). Phytochemical changes in stored young coconut. Phillippines Agriculture, 60, 256-270.

8. Elzebroek, A.T.G. And Koop W., (Eds). Guide to Cultivated Plants. CABI. 2008, 186-192.

9. Kalaikannan, A., A. S. R. Anjanuyulu and D. Santhi (2007). Effect of egg proteins on the quality and refrigerated storage life of chicken patties makes with broiler spent hen meat and by products. Int. J. Fd. Sci. And Technol., 42: 579-586.

10. Kumar, M. And B.D.Sharma (2003). Quality characteristics of low fat pork patties containing milk co-precipitates. Asian Aus. J. Anim. Sci., 16(4) : 588-595.

11. Manisha DebMandal., Shyamapada Mandal Asian Pacific Journal of Tropical Medicine (2011) 241-247

12. Martens $T$ (1995). Current status of sous vide in Europe. In: Principles of Modified Atmosphere and Sous Vide Product Packaging (Eds JM Farber \& KL Dods), pp. 37-68. Technomic Publishing, Inc: Lancaster.

13. Raut, K.A. (2007). Studies on quality of enrobed chicken patties, M.V.Sc. Thesis, MAFSU, Nagpur.

14. Rosengarten, Frederic, Jr. The Book of Edible Nuts. Dover Publications, 2004. pp. 65-93.

15. Tejano, E. A., State of the Art of Coconut Coir Dust and Husk Utilization (General Overview). Paper presented during the National Workshop on Waste Utilization, Coconut Husk held on November 12, 1984 at the Philippine Coconut Authority, Diliman, and Quezon City, Philippines. Philippine Journal of Coconut Studies. 1985

16. Thampan, P.K., Handbook on Coconut Palm. Oxford \& IBH Publishing Co. 1981

17. USDA. Factors that influence microbial growth. Human nutrition information service agriculture handbook. 2001. 
18. V.Y. Waisundara Waisundara, Conrad O. Perera, Philip J. Barlow Food Chemistry 101 (2007) 771-777

19. Varoquaux PJA, Nguyen-The C (1994). Vacuum processing: a new concept for pre-cooked fruit and vegetables. Proceedings. Food Science and Technology Today 8:42-9. 